\title{
箱根火山の東傾斜と丹那断層
}

\author{
吉田明夫*原田昌武* 小田原啓*
}

\section{Eastward Inclination of Hakone Volcano and Tanna Fault}

Akio YOSHIDA*, Masatake HARADA* and Kei ODAWARA*

\begin{abstract}
It is demonstrated that the eastern side of the Tanna fault has subsided relative to the western side using digital mesh data of geographic altitudes. The estimated subsidence is concordant with accumulated displacements of the Tanna fault and the fault slip at the 1930 Kita-Izu earthquake. Having noted that the eastern flank of Hakone volcano is steeper than the western flank, Suzuki (1971) concluded that Hakone volcano inclined to the east. This inclination of Hakone volcano is understandable if we note that it may be a manifestation of subsidence at the eastern side of the Tanna fault and its northern extension. We consider that subsidence at the eastern side of the Tanna fault represents a tectonic movement whereby the Manazuru block squared by the Tanna fault, Hirayama fault, Kannawa fault, and Kozu-Matsuda fault performs buoyant subduction. Based on the characteristics of crustal deformation at the Kita-Izu earthquake and aftershock distribution, it has been suggested that the western side of the Tanna fault moved south. Tectonically, this can be interpreted from the thesis that the western side of the Tanna fault, which had been dragged north by the subducting Manazuru block, rebounded at the KitaIzu earthquake.
\end{abstract}

Key words : Hakone volcano, Tanna fault, Kita-Izu earthquake, digital altitude data, buoyant subduction

キーワード : 箱根火山, 丹那断層, 北伊豆地震, デジタル標高データ, 浮揚性沈み込み

\section{I.はじめに}

鈴木（1971）は，箱根火山の東側斜面の方が, 西側斜面よりも傾斜角が大きいことを示して，箱 根火山は東に傾斜していると推定した。また，こ の傾斜は，国府津-松田断層による変位が，大磯 側に対する箱根側の相対的沈降を示していること とも調和的であると述べている。火山が自身の重 みによって変形することは珍しいことではない。 富士山や飯縄火山，岩木山などで火山体の荷重沈 下が知られている（鈴木, 1968）。しかし，火山 体が片方に傾くという例は聞かない。本小論で
は，箱根火山の斜面の傾斜が東側で急になってい ることを示す新たな事実を提示するとともに，そ の傾動は，実は丹那断層を境にその東側の地塊が 沈降していることの現れとみられることを指摘 し，伊豆半島北東部における衝突と沈み込みのテ クトニクスの観点から, その地形変動の意義を考 察する。

\section{II. 伊豆半島北東端部の地形の傾斜}

図 1 は伊豆半島北部の地形図である。実線は 活断層を表している。箱根火山の東側では早川, 須雲川による侵食があり，等高線も西側と違って

* 神奈川県温泉地学研究所

* Hot Springs Research Institute of Kanagawa Prefecture, Odawara, 250-0031, Japan 


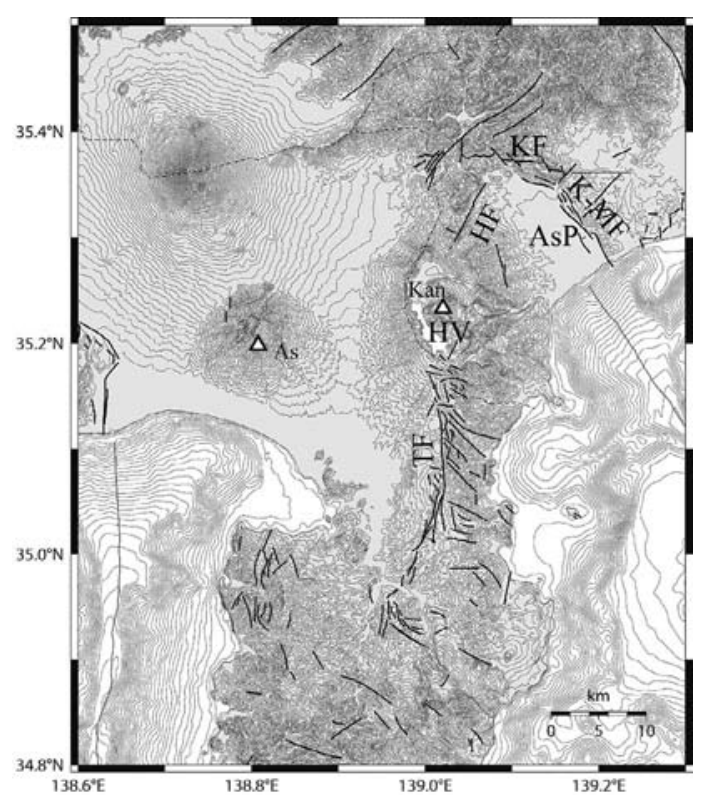

図 1 伊豆半島北部境界域の地形. 国土地理院の地 形図による、等高線の間隔は $50 \mathrm{~m}$. 実線は活 断層（活断層研究会, 1991）を示す. K-MF：国 府津-松田断層, $\mathrm{KF}$ : 神縄断層, $\mathrm{TF}$ : 丹那断層, $\mathrm{HF}$ : 平山断層, $\mathrm{AsP}$ : 足柄平野, $\mathrm{As}$ ：愛鷹山三 角点, Kan：冠ケ岳三角点.

Fig. 1 Topography in the northern boundary region of the Izu Peninsula from a topographic map of the Geospatial Information Authority of Japan. Contour interval is $50 \mathrm{~m}$. Solid lines indicate surface traces of active faults (Research Group for Active Faults, 1991). K-MF: Kozu-Matsuda Fault, KF: Kannawa Fault; TF, Tanna Fault; HF: Hirayama Fault; AsP: Ashigara Plain; As: Ashitakayama triangular point, Kan: Kanmurigatake triangular point.

南北走向でないので，鈴木（1971）が指摘したよ うな，カルデラ外縁の東側の方が西側よりも傾斜 が急という特徴を地形図からただちに読み取るこ とは難しい。しかし，箱根火山の南側の地域まで 含めて眺めると，ほぼ丹那断層を境に，その東側 の方が西側よりも等高線が混んでいる様子がみえ る。

丹那断層を境に西側に比べて東側の方が地形の 傾きが急であること，そして箱根火山の東斜面が 西斜面よりも急傾斜であることは，国土地理院に よる $50 \mathrm{~m}$ メッシュのデジタル標高データを使っ
て求めたメッシュ内の平均傾斜角の分布図（図 2a）において，丹那断層とその北側延長を境にそ の東側で，傾斜角が大きいことを示す暖色系が目 立っていることから容易にみてとれる。図 $2 \mathrm{a} の$ 長方形で囲った丹那断層の南部域では, 断層の東 側がむしろ緩傾斜になっているが，その領域では 図 $2 \mathrm{~b}$ にみるように，中部以北とは反対に丹那断 層の東側においても傾斜方向が西落ちとなってい ることに注意したい。図 3 は，上述の特徴をよ り定量的に示すために，丹那断層の両側および箱 根火山の東西の斜面を通る南北方向の測線に沿っ て，傾斜角がそれぞれどのように変化しているか を比較してみたものである。これから箱根火山か ら丹那断層の中ほどまで, 明らかに西側に比べて 東側で傾斜角が大きく, 傾斜方向が西落ちに変わ る南部の領域 (図 $3 \mathrm{c}$ の北緯 $35^{\circ} 04^{\prime}$ 以南) で緩傾 斜となっていることがわかる。丹那断層を境にし た地形傾斜角のこうした差異は, 次に述べる丹那 断層の変位の特徴を考慮すると理解できる。

丹那断層は約 $1 \mathrm{~mm} /$ 年の左横ずれの動きを伴う A 級活断層である（活断層研究会, 1991）。Kuno （1936）は丹那断層を境にした川筋の食い違いや 地形の不整合性から，丹那断層の左横ずれの積算 変位が $1 \mathrm{~km}$ に達すると見積もっている。そして, 丹那断層の右側地塊を南側に $1 \mathrm{~km}$ 戻したとき, それでもなお, 断層左右での地形のつながりに不 自然さがみられるとして，それを解消するために は，西側地塊を $100 \mathrm{~m}$ 下げる必要があることを指 摘した。1930 年に北伊豆地震が発生して丹那断 層が動いた。そのときに三角測量や水準測量デー 夕をもとに推定された丹那断層の水平および鉛直 変動（Tsuboi, 1931, 1932）は, Kuno (1936) が 地形から見積もった地質学的な時間スケールでみ たときの変動の特徽とよく一致していた。また, 旧丹那トンネル内に生じた断層の位置は地表で観 測された断層の位置より西側にあったが（Kuno， 1936)，それはトンネル内に現われた断層面が高 角で西に傾いていたことと対応し, 上述の地質学 的な時間スケールでの断層変位の蓄積（西側の地 塊が東側の地塊に相対的に南へまた上方に移動) とも調和的であった。先に, 丹那断層の南部域で 
(a) Inclination angle

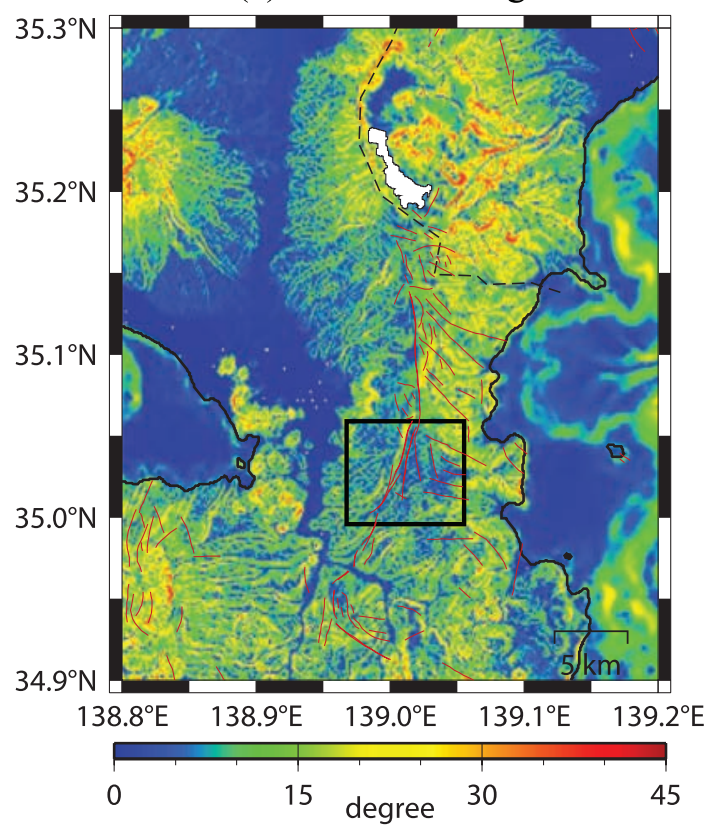

(b) Direction of inclination

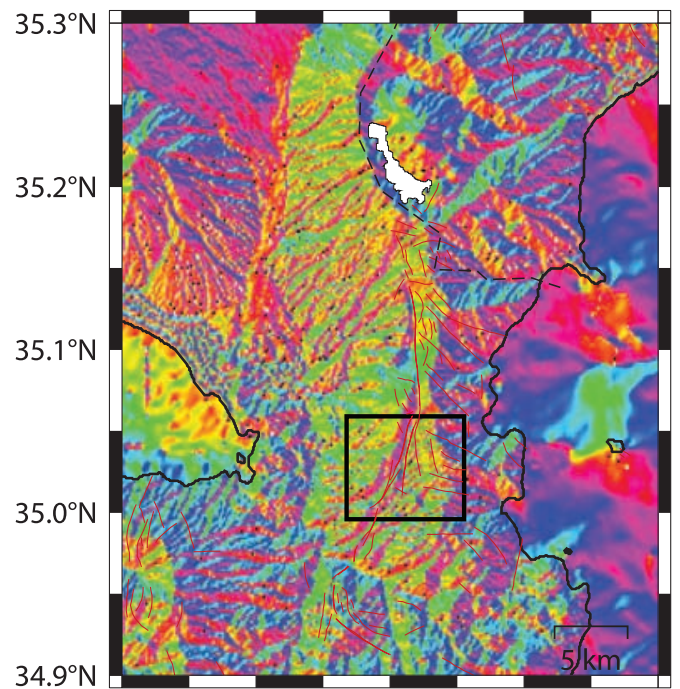

$\begin{array}{lllll}138.8^{\circ} \mathrm{E} & 138.9^{\circ} \mathrm{E} & 139.0^{\circ} \mathrm{E} & 139.1^{\circ} \mathrm{E} & 139.2^{\circ} \mathrm{E}\end{array}$

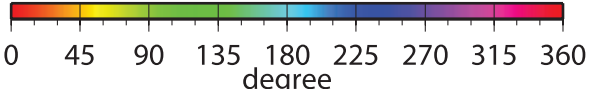

図 2

Fig. 2
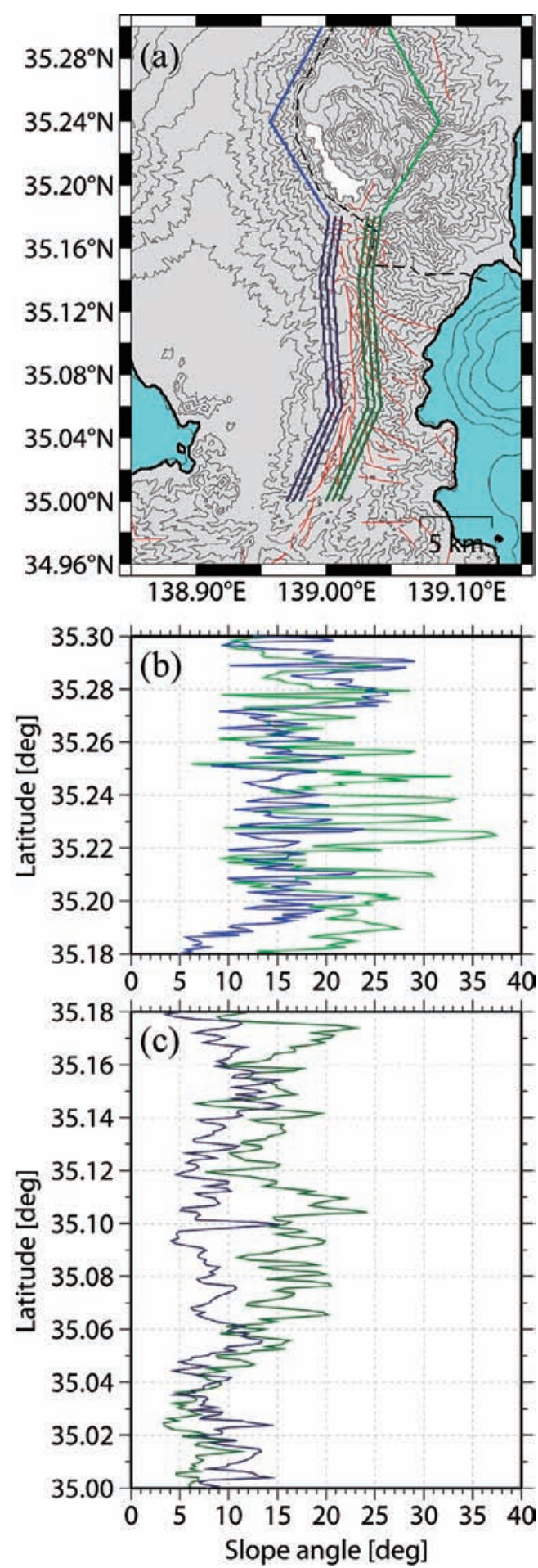

図 3

Fig. 3 
傾斜角が断層東側で緩やかになっている傾向がみ えるのは，その領域で地形が西傾斜になっている ことが関係していると述べた。丹那断層の動きに よって西傾斜の地塊が東に傾くように沈下する と，その西落ちの傾斜角は緩やかになる。した がって，傾斜角が緩やかという事実が，まさに丹 那断層の東側地塊の沈下を表していることにな る。

ところで，Tsuboi（1932）は，1930 年の北伊 豆地震時に実際に動いたのは丹那断層の西側地塊 であったと推定している。その根拠は, 愛鷹山一 箱根冠ケ岳 (それぞれの三角点の位置については 図 1 を参照）を結ぶ測線の方位が変わらなかった （箱根冠ケ岳の三角点は，そこから愛鷹山を望む ほぼ東西方向の測線に垂直な方向には動かなかっ た）として解析したときに，断層の西側では東側 に比べて相対的に断層線から遠く離れた三角点ま で大きな変位が生じていることと，断層西側南部 で地盤の隆起が観測されたことである。再決定さ れた北伊豆地震の余震の震源のほとんどすべて が，丹那断層の西側に分布すること (Yoshida and Hamada, 1991）や，地震時の被害が断層東側に 比べて西側の広い範囲で生じたことも, 北伊豆地 震時に断層の西側の地塊が動いたことを示唆す る。

なお， 1930 年北伊豆地震の際に丹那断層系で 生じた断層変位が松田（1972）によってまとめら れている。それによると, 西北西-東南東走向の
姫之湯断層等が右横ずれだったほかは，南北走向 のおもな断層はすべて左横ずれで，水平ずれ成分 に関しては地形をもとにKuno（1936）が推定し た変動の特徴とよく一致していた。しかし，垂直 成分については，断層系全体にわたって東落ちと いうことではなく，場所によって西落ちのところ もみられた。とくに主断層である丹那断層の北部 やその北への延長にあたる箱根町断層では東側隆 起であったと記載されている。一般に横ずれ断層 であっても，屈曲部や不連続なところで垂直変位 が生じ, また，断層末端付近では，変位の向かっ た先の側で隆起が観察されることは珍しくない。 こうしたことから, 丹那断層系のように活動度の 高い断層が何故そこに存在するかというようなテ クトニクス上の意義を考察する場合には，一回一 回の地震発生に伴って個々の場所で生じた垂直変 位の分布がどうであったかということよりも，地 質学的な時間スケールで何十回，何百回と繰り返 した断層運動によって累積した，地形的に認めら れる断層系全体としての特徵的な変位の方に注目 するのがより適当ではないかと考える。

\section{III. 議 論}

著者たちは前節において，鈴木（1971）によっ て指摘された箱根火山の東への傾動は火山体が傾 いたということではなく，丹那断層とその延長部 を境にした伊豆半島北東端部の地塊の相対的な沈 下の現れの一環であるという見方を提出した。前

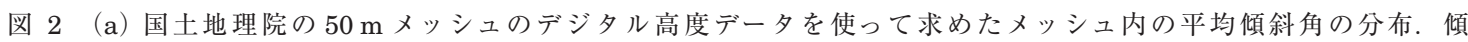
斜角は水平からの傾き.（b）同データを使って求めたメッシュ内の平均傾斜方向の分布. 傾斜方向は南か ら時計回りに計った角度.（a)，（b）両図のなかの矩形領域については本文参照.

Fig. 2 (a) Average inclination angle in each mesh of $50 \mathrm{~m}$ by $50 \mathrm{~m}$ obtained by using digital mesh data of altitude with $50 \mathrm{~m}$ meshes of the Geospatial Information Authority of Japan. The inclination angle is measured from the horizontal plane. (b) Average direction of the inclination in each mesh of $50 \mathrm{~m}$ by $50 \mathrm{~m}$ obtained by using the same data. Direction of the inclination is measured clockwise from the south. See explanations in the text for rectangular regions in both maps.

図 3 丹那断層の東西および箱根火山の東西の斜面における地形傾斜角の比較.（a）に示した線に沿っての，箱 根火山の東西の斜面での傾斜角の南北方向の変化を（b）に，また，丹那断層の東西のそれぞれ 3 本の線に 沿う傾斜角の平均值を(c) に示す.

Fig. 3 Comparison of inclination angles along the blue and green lines shown on map (a). (b) Variations of the inclination angles between the western and eastern flanks of Hakone volcano. (c) Variations of average inclination angles at the western and eastern sides of the Tanna fault along each of three blue and green lines, respectively. 
述したように, Kuno（1936）は，丹那断層の地 学的な時間スケールでの変位の蓄積は, 西側地塊 に相対的な東側地塊の北方への移動だけでなく, 東側が沈下する成分をもつことを示している。 1930 年北伊豆地震の際に, 当時掘削中のトンネ ル内でみられた断層面のずれの動きも，そうした 地学的なスケールでの変位の蓄積の仕方に一致す るものであった（Kuno, 1936）。

ここで興味深いのは, 北伊豆地震の際の地殼変 動や余震分布，それに被害状況にみられる断層の 東と西での非対称性から，先述したように，地震 時に動いたのは断層西側の地塊だったと推定され ていることである。われわれは，このことは丹那 断層のテクトニックな意義を考える上で重要な点 であると考える。図 4 は，国土地理院が日本列 島に展開している GPS 連続観測網 (GEONET) の各観測点における水平変位速度の空間分布をみ たものである（固定点は山梨県の牧丘）。この分 布図で注目したいのは，丹那断層とその北方延長 をほぼ境にして，その両側で変位ベクトルの方位 および大きさに顕著な差異が認められ，西側領域 では北向きの変位がほとんどみられないことであ る。防災科学技術研究所の臼田を起点とした GPS 観測網の変位速度図でも同様の特徵をみる ことができる（防焱科学技術研究所, 2010)。現在 を地震間の状態であるとすると，これは，通常時 においては断層の東側領域が本州島弧に対して能 動的に北に変位しているのに対して西側領域には そうした動きがみられないことを示している。こ のことから, 北伊豆地震の際の断層運動で西側地 塊が動いたと推定されることは，平時に東側地塊 の北向きの動きに引きずられていた西側地塊が地 震時に反発したと考えれば理解できる。ところ で，平時において丹那断層の西側地塊が真鶴ブ ロックの動きに引きずられているなら, 丹那断層 を境に変位はその両側でむしろ連続になるのでは ないかとも推測されるが，図 4 の GPS 観測点網 はそのことを確かめられるほど十分に稠密ではな い。丹那断層近傍での地塊の動きの詳細をみるに は，丹那断層を東西に横切る測線上で多点の観測 を実施する必要がある。将来，そうした観測に

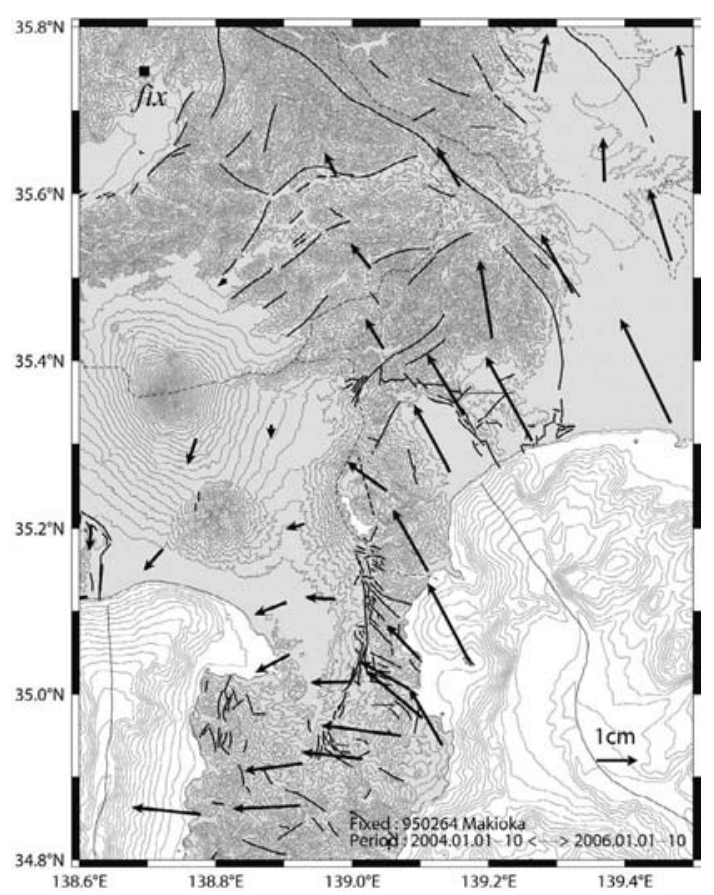

図 4 国土地理院の GPS 連続観測網の観測点におけ る水平変位速度. 矢印の方位と長さは山梨県 牧丘を固定点としたときの，2004 年 1 月 1 日 から 2006 年 1 月 1 日までの各観測点における 水平変位を示す

Fig. 4 Horizontal velocity at GPS stations of the Geospatial Information Authority of Japan. Direction, Lengths of arrows indicate horizontal displacements during the period from January 1 , 2004 through January 1, 2006.

よって，例えば深部で常時ずれの動きがあり，浅 部で固着しているという状況を把握することがで きるかもしれない。今後の研究を待ちたい。

なお，水準測量から求めた日本列島 100 年間 の地殼上下変動図（国見ほか, 2001）でも，真鶴 半島を含む伊豆半島北東端部で沈降し, 丹那断層 付近を境にその西側で相対的に隆起している様子 が，あまり明暸ではないもののみてとれる。

丹那断層のこのような動きの意味をプレート・ テクトニクスの視点で敷衍するなら，丹那断層を 西の境界，そして神縄断層系を北の境界，国府 津一松田断層系を東の境界とする領域（ここでは この領域を真鶴ブロックと仮称する）が，相模卜 
ラフから沈み込むフィリピン海プレートの動きに 乗って沈下しながら北に向かって進んでいて，そ の動きに平時は引きずられている上盤側の大磯丘 陵や丹沢, 丹那断層西側の地塊が, 地震時に反発 して逆向きに変位するということになる。この考 え方を模式的に図 5 に示す。真鶴ブロックの境 界として, 丹那断層, 平山断層, 神縄断層系, 国 府津-松田断層系, 相模卜ラフと続くところは比 較的はっきりしているが, 南の境界はあいまいさ がある。図 5 では, ほぼ丹那断層南端の北西-南 東走向の共役断層に沿って線を引いているが，実 際にはその北東側の伊豆単成火山分布域全体が境 界ゾーンを構成していると考えられる。一般に単 成火山は引張場でみられること，伊豆半島東方沖 の群発地震活動が北西-南東走向のダイクの貫入に よって生じている (Okada and Yamamoto, 1991) こと等は, そこが北東-南西方向に引っ張られる 張力場になっていることを示唆している。

図 5 に示したような考え方を最初に述べたの は, 伊豆単成火山群域・丹那断層・平山断層を境 界とする伊豆半島北東端の領域が, 駿河湾から沈 み达む伊豆半島主部と別れて北向きに移動してい くという仮説を提出した吉田ほか（1979）であ る。その後, Ito et al. (1989) は, 沈み达みから 衝突に変わった伊豆半島北部のテクトクスの変遷 を推定するなかで，同領域のとくにその北部境界 での, 各ステージにおける断層運動の様式と応力 場を論じた。そして, Koyama and Umino (1991) は，伊豆単成火山群がそこに存在することの意義 を強調しながら，吉田ほか（1979）と同様の考え に立脚して, 伊豆半島北東部における地殼の変形 を議論している。また, 吉田（1993）は, 1930 年北伊豆地震以後の神奈川県西部から山梨県東部 にかけての震源分布や伊豆半島東方沖の群発地震 の特徵を, 伊豆半島の変形テクトニクスと関連づ けて考察した。

丹那断層の動き, 丹那断層およびそれを北へ延 ばした線を境にした地形傾斜角の違い，GEONET で観測される地殼の変形，それに国府津-松 田断層の変動地形は, 丹那断層から箱根, 平山断 層, 神縄断層系, 国府津-松田断層系で区切られ

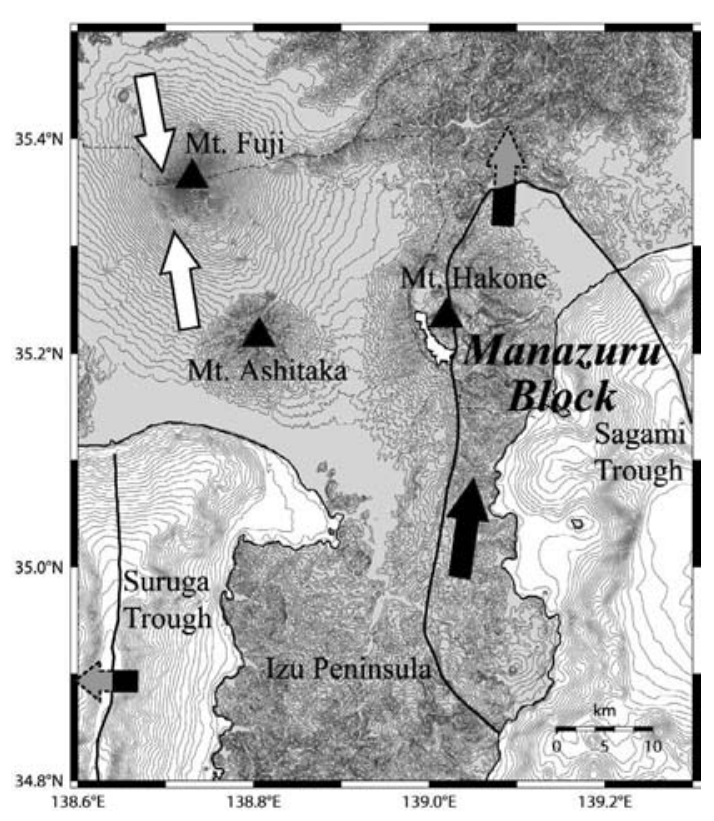

図 5 真鶴ブロックの境界と伊豆半島北部域におけ る伊豆半島の変形を示す模式図. 真鶴ブロッ クは北部境界で丹沢山塊の下に潜り込んでいる. 一方, 伊豆半島の主部は駿河湾から東海地域 下に沈み込んでいる。また，富士山周辺では 南北方向に押し合っている.

Fig. 5 A map showing boundaries of the Manazuru block and deformation of the northern region of the Izu Peninsula. The Manazuru block is performing buoyant subduction on the northern boundary. The principal part of the Izu Peninsula is subducting on the Suruga Trough and colliding with the land plate around Mt Fuji.

た真鶴ブロックが，フィリピン海プレートの動き に伴って浮揚性の沈み込みをしているという，本 論文の基本的な考え方の妥当性を示している。た だし，真鶴ブロックはフィリピン海プレートに しっかりと乗って，それといっしょに同じ速度で 沈み込んでいるとは考えられない。丹那断層や国 府津一松田断層のずれ速度は神奈川県西部域にお けるフィリピン海プレートと陸側のプレートの相 対運動速度に比べて 1 桁小さい。では, この差 はどこで解消されているのか。この問題を考える にあたって, 真鶴ブロックの下には, フィリピン 海プレートと陸側のプレートのカップリングに起 因する関東地震の震源域が存在することに注意し 
たい。おそらく，フィリピン海プレートと陸側の プレートの相対運動の大部分は, 関東地震の震源 域に相応するプレート境界で費消されているとみ られる。しかし，これまで，関東地震の発生間隔 は南海トラフ沿いのプレート境界地震よりも長い ことから，この地域のプレート間相対運動は，何 か別の形でも進行しているのではないかと推定さ れてきた。真鶴ブロックの浮揚性沈み达みは，そ の別の形の相対運動の一つの候補とみることがで きる。さらにこのほかの候補として, 相模湾, 東 京湾下の地震の震源分布やメカニズムの特徵か ら, 関東地震の震源断層を形成する面の下にもう 一つプレート相対運動を担う境界面の存在が推測 されている（吉田ほか, 2007）ことも指摘してお く。これら関東下に沈み込んでいるフィリピン海 スラブの西縁はどこか, その西縁と丹那断層とは どのような関係にあるかは, 伊豆半島の衝突およ び沈み込みテクトニクスを十全に理解する上で非 常に重要な問題であるが, それを論じるのは本小 論の範囲を超えるので, 将来の研究課題とした い。

なお, 真鶴ブロックの北端部で, 地質学的な最 新の時代に, 浮揚性沈み込みに伴う相対運動がど この断層で生じているかについては明らかでない ように思われる。徐（1995）は，神縄断層付近は すでに衝突域に移って，相対運動はその南にある 日向断層のところで生じているという考えを提出 した。Odawara et al. (2010) は，日向断層でな く, それと平行に走る内川断層が相対変位の主要 な部分を担っているのではないかと考えている。 先述したように, 地形変動や GPS 観測から, 真 鶴ブロックの西側境界が丹那断層から箱根火山を 縦断してその北方に続いているのは確かと考えら れるが，平山断層の活動度は丹那断層や国府津松田断層に比べると低いと推定されるので（Ito et al., 1987), 真鶴ブロックの北西〜北境界にお ける運動形態については, 今後, さらに詳しい検 討が必要なように思われる。また，箱根カルデラ のなかを南北に縦断する断層は知られていない が, 2001 年以降に 3 回観測されている箱根火山 の膨張歪変動は, 中央火口丘下に南北走向の開口
割れ目が生じたと考えることによって説明できる ことが示されており（原田ほか, 2009)，そのよう な弱面がプレート相対運動の一端を担っている可 能性が考えられる。

\section{IV. まとめ}

丹那断層を境にその東側が西側に相対的に沈降 していることを，標高のデジタルメッシュデータ を用いて示した。この沈降はKuno（1936）に よって推定された丹那断層の変位の蓄積および 1930 年北伊豆地震の際の断層変位と整合的であ る。鈴木 (1971) は, 箱根火山の東側斜面の方 が，西側斜面よりも傾斜角が大きいことを指摘し て, 箱根火山は東に傾斜していると想定したが, この箱根火山の東傾斜も, 丹那断層を北へ延長し た線の東側が沈降していることの現れとみなすこ とができる。丹那断層の東側地塊の沈降は, 伊豆 単成火山群域, 丹那断層, 平山断層, 神縄断層 系，そして国府津一松田断層系を境界とする真鶴 ブロックが，フィリピン海プレートの動きに乗り つつ浮揚性沈み込みをしているために生じている と考えられる。北伊豆地震の際には地殼変動や余 震分布から, 丹那断層の西側地塊が動いたと推定 されるが，そのことは，平時に沈降しつつ北へ向 かって進む真鶴ブロックに引きずられた丹那断層 の西側地塊が地震時に反発したと考えれば理解で きる。

\section{謝 辞}

傾斜角および傾斜方向の解析に国土地理院のデジタ ル標高デー夕を, また, 変位速度べクトル図の作成に 同院の GPS 観測データを使用させていただきました。 記して謝意を表します。二人の匿名の査読者からは, 原稿を改善する上で有用な多くの助言をいただきまし た。深く感謝します。

\section{文献}

防災科学技術研究所 (2010): 関東地方の GEONET 観 測網による地款変動 (2006 年 11 月～2009 年 11 月). 地震予知連絡会会報, 83, 135-138. [National Research Institute for Earth Science and Disaster Prevention (2010): Report of CCEP, 83, 135-138.]

原田昌武・小林昭夫 - 細野耕司・吉田明夫 (2009): 2001 年箱根群発地震活動以後の箱根から富士山にか 
けての地殼変動. 温泉地学研究所研究報告, 41, 7-14. [Harada, M., Kobayashi, A., Hosono, K. and Yoshida, A. (2009): Bulletin of the Hot Springs Research Institute of Kanagawa Prefecture, 41, 7-14.]

Ito, T., Uesugi, Y., Yonezawa, H., Kano, K., Someno, M., Chiba, T. and Kimura, T. (1987): Analytical method for evaluating superficial fault displacement in volcanic air-fall deposits: The case of the Hirayama fault, south of Tanzawa mountains, central Japan, since 21500 years B.P. Journal of Geophysical Research, 92, B10, doi:10.1029/JB092iB10p10683.

Ito, T., Kano, K., Uesugi, Y., Kosaka, K. and Chiba, T. (1989): Tectonic evolution along the northernmost border of the Philippine Sea plate since about 1 Ma. Tectonophysics, 160, 305-326.

活断層研究会 (1991): 新編 日本の活断層一分布図と 資料. 東京大学出版会， 437p. [Research Group for Active Faults of Japan (1991): Active Faults in Japan. University of Tokyo Press, 437p.]

Koyama, M. and Umino, S. (1991): Why does the Higashi-Izu monogenetic volcano group exist in the Izu Peninsula?: Relationship between late Quaternary volcanism and tectonics in the northern tip of the Izu-Bonin arc. Journal of Physics of the Earth, 39, 391-420.

国見利夫 ·高野良仁・鈴木 実 ·斎藤 正 - 成田次範 · 岡村盛司 (2001): 水準測量データから求めた日本列 島 100 年間の地殼上下変動. 国土地理院時報, 96, 23-37. [Kunimi, T., Takano, Y., Suzuki, M., Saitou, T., Narita, T. and Okamura, S. (2010): Journal of the Geographical Survey Institute, 96, 23-37.]

Kuno, H. (1936): On the displacement of the Tanna fault since the Pleistocene. Bulletin of the Earthquake Research Institute, University of Tokyo, 14, 619-631.

松田時彦 (1972): 1930 年北伊豆地震の地震断層. 星野 通平・青木 斌編：伊豆半島. 東海大学出版会, 7393. [Matsuda, T. (1972): Izu Hanto edited by Hoshino, M. and Aoki, H., Tokai University Press, 7393.]

Odawara, K., Aketagawa, T. and Yoshida, A. (2010): Kozu-Matsuda fault system in northern Izu colli- sion zone, western part of Kanagawa Prefecture, central Japan. AGU Fall Meeting, T11B-2065.

Okada, Y. and Yamamoto, E. (1991): Dyke intrusion model for the 1989 seismovolcanic activity off Ito, central Japan. Journal of Geophysical Research, 96, 10367-10376.

徐 垣 (1995): 足柄層群南縁の衝上断層 (日向断層) と そのテクトニクス上の意義. 地質学雑誌，101，295303. [Soh, W. (1995): Journal of the Geological Society of Japan, 101, 295-303.]

鈴木隆介 (1968): 火山体の荷重沈下。火山 2, 13, 95108. [Suzuki, R. (1968): Bulletin of Volcanological Society of Japan, 13, 95-108.]

鈴木隆介 (1971): 箱根火山の地形. 日本火山学会編 : 箱 根火山. 7-42. [Suzuki, R. (1971): Hakone Kazan edited by Volcanological Society of Japan, 7-42.]

Tsuboi, C. (1931): On the results of repeated precise levellings around Idu Peninsula. Bulletin of the Earthquake Research Institute, University of Tokyo, 9, 271-290.

Tsuboi, C. (1932): Investigation on the deformation of the earth's crust in Idu Peninsula connected with the Idu earthquake of Nov. 26, 1930. Bulletin of the Earthquake Research Institute, University of Tokyo, 10, 435-448.

吉田明夫 (1993): 神奈川県西部およびその周辺の地震活 動とテクトニクス. 地学雑誌, 102，407-417. [Yoshida, A. (1993): Journal of Geography (Chigaku Zasshi), 102, 407-417.]

Yoshida, A. and Hamada, N. (1991): Redetermination of hypocenters of foreshocks, main shock and aftershocks of the Kita-Izu earthquake and the Ito earthquake swarm of 1930. Journal of Physics of the Earth, 39, 329-344.

吉田明夫・藤井洋一郎·今永 勇 $(1979)$ : 伊豆半島周 辺域のテクトニクス. 地震学会春季講演予稿集, A53.

吉田明夫・野口伸一・細野耕司 (2007): フィリピン海 プレート北端部におけるスラブの二重沈み込み。日 本地球惑星科学連合 2007 年大会, S228-002.

(2010 年 11 月 1 日受付, 2011 年 5 月 16 日受理) 